\title{
Robert Jameson's transition from Neptunism to Plutonism as reflected in his lectures at Edinburgh University, 1820-1833.
}

\author{
Philip Stone \\ British Geological Survey, The Lyell Centre, Edinburgh EH14 4AP, UK \\ Correspondence: psto@bgs.ac.uk
}

\begin{abstract}
Robert Jameson is generally remembered for championing Neptunist geology (originated by Abraham Werner) during its early $19^{\text {th }}$ century competition with the rival Plutonist theory (initiated by James Hutton). Hutton's ideas prevailed, and Jameson's intellectual transition to Plutonism is documented in the surviving notes taken by students who attended his lectures at Edinburgh University: one early record is from 1809, a second record is from c.1820, and four sets of notes are from the early 1830s. Of the latter four, two have not been previously considered from a geological perspective and prove to be the most revelatory of Jameson's conversion; notes compiled by the Royal Navy surgeon Robert McCormick are particularly comprehensive. Although Jameson attempted to maintain the essentials of Werner's theory for its well-ordered stratigraphy, he progressively adopted a Plutonist approach to more contentious issues such as the origin of granite, veining, and mountain building. Jameson used Edinburgh's Salisbury Crags sill for field demonstrations and the students' notes illustrate his changing views in terms of the origins of this classic geological feature. Of the students whose lecture notes survive, it is only McCormick for whom Jameson appears to have been a lasting geological influence.
\end{abstract}

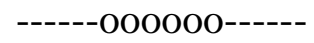

For the first third of the nineteenth century Edinburgh University was the principal setting for one of geology's great controversial debates: Neptunism versus Plutonism. The Neptunist theory had been developed by the German mineralogist Abraham Werner (1750-1817) who envisaged all rocks to form a single succession developed in a global, but receding ocean, accumulating first by chemical precipitation (resulting in granite and gneiss, other crystalline rocks and some limestones), then by erosion and the deposition of clastic sedimentary rocks; only relatively young volcanic rocks were ascribed an igneous origin. Werner's ideas were adopted and championed by Robert Jameson (1774-1854), Regius Professor of Natural History at Edinburgh University for fifty years, from 1804 until his death (Figure 1). The alternative, Plutonist theory arose from the ideas of James Hutton (1726-1797) who is now best remembered for his recognition of 'deep time' during which were developed successive cycles of deposition, uplift and erosion, with igneous rocks such as granite intruded from depth and then crystallised from a hot, molten magma. Hutton's geological ideas were promulgated at Edinburgh University by Thomas Charles Hope 
(1766-1844), Professor of Chemistry, and by John Playfair (1748-1819), Professor of Mathematics. There is an extensive literature on this dispute: for example, Jameson's Neptunist interpretations were neatly summarised by Bailey \& Tait (1921), their origins have been examined by Sweet \& Waterson (1967), and their scientific basis contrasted with Hutton's Plutonist geology by Flinn (1980), Secord (1991a) and Jenkins (2016). A scholarly overview was provided by Laudan (1987, pp. 87-137) who also discussed the areas in which Hutton's original proposals were subsequently found wanting and so were modified by his successors.

At the beginning of the $19^{\text {th }}$ century variations on Werner's geological Neptunism were commonly held views, but over the next two or three decades were largely rejected in favour of interpretations that derived from Hutton's Plutonist proposals, with internal heat seen as the driving force behind the Earth's geological processes. Those who had adopted Neptunist ideas were subsequently mocked by influential commentators such as Sir Archibald Geikie:

The theory of a primeval ocean that overtopped the mountains, which formed the basis of Werner's teaching, led in every direction to such manifest contradictions and absurdities, that we need a little patience and some imagination to picture to ourselves how it could have been received and fervently believed in by men of intelligence.

(Geikie, 1897, p. 117).

Jameson's obituary, albeit compiled by his nephew Laurence Jameson (1854), contains generous testimonials from his peers, but dismissive repudiations such as Geikie's ensured that he came to be regarded simply as a reactionary adherent to Werner's geological theory long after it had been superseded by Hutton's ideas. This view persists despite contrary evidence. For example, Flinn (1980) drew attention to contemporary acknowledgements of Jameson's acceptance of Hutton's ideas in the 1830s including that by Fitton (1839, p. 455, footnote) who wrote that Jameson "has long since expressed his conversion to Huttonian theory with the utmost frankness and, on several occasions given the weight of his testimony to the genius of its author." According to Sweet (1976, p. xviii) "[t]he exact date of his "conversion" is not known, but ... it might have been gradual as a result of evidence produced by other workers during the second decade of the nineteenth century." In his published work, Jameson used Wernerian stratigraphical terminology until at least 1826, as in the following example from his interpretation of geological observations made during the Arctic expeditions led by William Parry (1790-1855): “The limestone associated with gypsum in North Somerset [Island] may safely be referred to the second secondary limestone formation, the first or oldest floetz [flat lying] limestone of Werner" (Jameson 1826, p. 147). However, this does not necessarily imply a causal Neptunist interpretation of the rocks' origins. 
Specific details of Jameson's changing views can be gleaned from the surviving notes taken by students attending his renowned course of natural history lectures. Six such records are known to the author (Table 1), only three of which appear to have been previously mentioned in the geological literature and none of which have been fully assessed in terms of Jameson's role in the Neptunist-Plutonist debate. The earliest record, from 1809, dates from a time when Jameson's views were determinedly Neptunist. This paper reviews the students' notes from later periods and establishes the 1830-1833 interval as pivotal in Jameson's acceptance of Plutonism.

\section{Robert Jameson (1774-1854)}

Jameson studied with Werner at Freiberg, Germany, in 1800-1801 and on his return to Edinburgh he vigorously promoted Werner's Neptunist theory in opposition to the alternative Plutonist theory originated by Hutton. Jameson's supposed adherence to Wernerian ideas long after they had been generally rejected has tended to diminish his intellectual reputation (Geikie 1897) but, conversely, he was an early convert to some of the latest, and radical, scientific views. As early as 1826 he was a closet

Lamarckian transmutationist (Secord 1991b) and from then until the 1840s was one of the few proponents of a previously widespread glaciation in Scotland (Davies 1969, pp. 265-267; Sweet 1976, p. xviii) although his interpretation of the huge glacial erratics observed during Parry's Arctic expeditions still maintained "that the boulders or rolled blocks met with in different quarters, and in tracts distant from their original localities, afford evidence of the passage of water" (Jameson 1826, p. 150).

Jenkins (2016, p. 528) found ample evidence that Jameson was by most accounts "an energetic and diligent professor", but conversely, his reputation has suffered from the criticisms levelled by many of his ex-students and Flinn (1980) detailed several examples. One much-cited dismissal is that recalled in his autobiography by Charles Darwin (1809-1882), who attended Jameson's course in 1826-1827 winter session:

During my second year at Edinburgh I attended Jameson's lectures on Geology and Zoology, but they were incredibly dull. The sole effect they produced on me was the determination never as long as I lived to read a book on Geology, or in any way to study the science."

(Barlow, 1958, p. 52).

But whatever Jameson's might have lacked in charisma, his stamina was not in doubt. The Royal Navy surgeon Robert McCormick (1800-1890), who attended the lecture course in the winter of 1830-1831, abandoned his notetaking during Jameson's second lecture - Monday 22 November 1830, "On the effects of heat and cold" - with the rather plaintive comment "continued for three hours". 
Other students had more positive experiences. The whaling captain and Arctic explorer William Scoresby (1789-1857) attended Edinburgh University in the winter sessions of 1806-1807 and 1809-1809; during the latter period he followed Jameson's lectures. From subsequent correspondence between the two men, Stamp \& Stamp (1975, p. 34) concluded that Jameson was "an enthusiastic and kindly man who had a great gift for arousing enthusiasm in others ... a brilliant teacher." Scoresby found Jameson inspirational (Devlin 2019, p. 34) and in return provided him with Arctic specimens for his natural history museum: amongst them was a live Polar Bear cub, delivered in 1812. Jameson acknowledged the bear's safe arrival noting that "I have brought that animal to the college where he is now lodged in a commodious den" (Stamp \& Stamp 1975, p. 47; Devlin 2019, p. 35). In further marks of appreciation Scoresby dedicated to Jameson his celebrated book - An account of the Arctic Regions - published in 1820 and named Jameson Bay (Jamesonbukta) in Jan Mayen island. It may be significant that Scoresby encountered a much younger Jameson than did the other students whose comments have survived.

Despite the criticisms of Jameson's scientific stance and lecturing abilities his course was immensely popular and " $[t]$ he Army Board recommended his class because it taught recruits leaving for the colonies how to keep records of the flora and fauna" (Desmond \& Moore 1991, p. 42). Curiously, and in contrast to his supposedly brusque and dry-as-dust lecturing persona, Jameson seems to have been sociable and hospitable to at least some students on a personal level. Scoresby was a frequent dinner guest (Stamp \& Stamp 1975, p, 36) whilst McCormick described how, on 6 April 1831, acting "on an invitation from Professor Jameson, I attended a musical soirée, at his house in the Royal Circus" (McCormick 1884b, p. 216). There was probably some self-interest in Jameson's hospitality, with those students entertained whom he had identified as likely future travellers and potential contributors to his museum collection. There is no record of the teenage Darwin being singled-out for this special attention.

Whatever students thought of Jameson's lecturing abilities, one of the main attractions of his course was the access it provided to his jealously guarded natural history museum (Chitnis 1970) - which by the time of Jameson's death in 1854 contained in excess of 74000 items (Jameson 1854). McCormick noted that as well as seeing the public exhibits, he was also able to visit Jameson's personal collection "in the rooms opposite to the side on which the public museum stands" (McCormick 1884b, p. 216). For most of his students, the demonstrations of material in the museum were probably of more interest than the formal lectures and they were expected to attend three times a week for practical work (Browne 1995, p. 72). Jameson had developed the collection to the extent that it was recognised as one of the finest in Europe and enjoyed receipt of a goodly proportion of the specimen collections brought back to Britain by the succession of Royal Navy expeditions dispatched to the Arctic during the first half of the $19^{\text {th }}$ century (Sweet 1976, p. xvii). Some can still be traced: for example, some of the fossil specimens from Parry's third expedition in search of a 
'North West Passage' (1824-1825), originally described by Jameson (1826) are now part of the National Museums Scotland collection (Lee 1912).

\section{Jameson's lecture course}

Six records of Jameson's lecture course have been identified (Table 1) and have the appearance of summaries copied-up from original notes. Notebook details and biographical information for the students concerned is contained in Appendix 1. The earliest record is that of William Scoresby from 1808-1809. At that early date Scoresby would have experienced Jameson's unambiguous presentation of Werner's Neptunist geological theory and his notes are not discussed further in this paper; they were utilised by Stamp \& Stamp (1975) in their biographical work. An undated set of notes (and effectively anonymous although preserved by William Dansey) is probably from about 1820. The evidence for this date, which is earlier than the 1826 date previously proposed by Jenkins (2016), is laid out in Appendix 1; the uncertainty is recognised. The four remaining records, by W. S. Walker, Robert McCormick, D. B. Ramsay and an anonymous student, span the early 1830 s.

The notes preserved by Dansey and those taken by Walker and Ramsay have been previously acknowledged in assessments of Jameson's scientific views (e.g. Jenkins 2016) but McCormick's notes and the anonymous record do not appear to have been previously examined from a geological perspective. The different accounts show that Jameson's courses did not always follow the same structure, nor did they always involve the same number of lectures, and at times Jameson randomly interspersed his natural history themes.

Of the available notes it is those of McCormick, from 1830-1831, that provide the chronologically best-ordered account of Jameson's lecture course, and they are helpfully supplemented by parts of his two-volume autobiography (McCormick 1884a, 1884b). McCormick's notes will be taken as the template for the following discussion. They show that Jameson's lecture schedule ran for five days a week, Monday to Friday, with two Saturday field visits in April to Arthur's Seat and Salisbury Crags. Individual pages of McCormick's notebook are not numbered, but each lecture is numbered and dated, hence subsequent citations herein refer to lecture number and date. As recorded by McCormick, the lecture course can be summarised as follows:

- Lectures 1-19, 19 November 1830 to 16 December 1830. Meteorology.

- Lectures 20-28, 16 December 1830 to 7 January 1831 (with a break from 25 December to 5 January). Hydrography.

- Lectures 29-52, 10 January 1831 to 9 February 1831. Geology.

- Lectures 53-97, 11 February 1831 to 15 April 1831. Mineralogy and Zoology. 
The mineralogy and zoology lectures were interspersed seemingly at random but, from the geological perspective, there were important interlocutions on the "geognostical structure and geology of Scotland" (lectures 84-89, 28 March to 5 April 1831) and the "geognostical structure and geology of England" (lectures 93 and 94, 11 \& 12 April 1831).

The geology lectures commenced with an account of "the physiography of the Earth's surface" then McCormick's notes confirm the contemporary ignorance concerning the Earth's interior:

Various opinions respecting the interior of the Earth - some suppose it to be occupied by Fire - others by condensed air or Light, with a floating Planet in the centre - some suppose it to be filled with Mineral Matter etc.

(McCormick, lecture 31, 12 January 1831)

Thereafter, Jameson presented an interpretation of the origin of rocks within the Neptunist classes defined by Werner, specimens were most probably passed amongst the students. The 'Dansey' notes feature a classic presentation of the Neptunist geological model of global structure in its simplest form but McCormick and the other students have sketches showing a rather less idealised interpretation. McCormick's version still maintains the basic Neptunist pattern but admits sub-surface volcanic rocks and more complicated, sill-like intrusions: "volcanic tortuous beds" (Figure 2).

McCormick records the rock sequence in terms of Werner's classes and describes their characteristics as follows:

1. Primitive rocks are the deepest and oldest class of rocks - specimens - granite, gneiss and mica slates. They are of a chemical formation and contain no mechanical deposits or fossil remains of any organic being - from which it is supposed that they were formed before the existence of plants or animals commenced.

2. Transition rocks - a mix of chemical and mechanical. Some fossils. Specimens - greywacke, limestone/corals.

3. Secondary rocks - conglomerate and sandstones. Mechanical deposits predominate, wide range and more perfect kinds of fossils.

4. Mostly mechanical deposits - fossils include birds and quadrupeds, no remains of Man. Hence it is supposed that Man was not called into existence at the period their formation took place.

5. Alluvial formations - some fossils of extinct forms others of animals that now exist. Remains of Man - not called into existence until of late period.

6. Volcanic or igneous - are of all ages and often arrive from the deepest parts of the crust. 
Of the classes of rocks described by Jameson, numbers 1 to 5 follow the Neptunist model, but the sixth class has been expanded to accommodate a greater range of igneous rocks; of significance here is the qualifier "of all ages". Nevertheless, igneous rocks were still largely restricted to varieties of 'trap' - basaltic and doleritic intrusions and lavas; granite was an uncomfortable fit in the Neptunist model.

\section{Granite and veins}

On a visit to Glen Tilt in the Scottish Highlands in 1785, Hutton had recognised the intrusive nature of granite veins cutting the local schist, the granite having been injected in a molten state. The 'Dansey' notes include several extended rebuttals by Jameson of Hutton's ideas, for example the following, in a discussion on the origin of veins:

The Huttonian theory ... is entirely at variance with existing appearances - the very foundation of such an hypothesis is at once overturned by the occurrence of veins entirely isolated, \& surrounded on all sides by heterogeneous rock" but then: "The same fact also much enfeebles the Wernerian doctrine.

('Dansey' volume 2, p. 31r)

Jameson's admission (at a relatively early date, c. 1820) that veins, and particularly granitic veins, caused a major difficulty for Werner's Neptunist theory is significant, for therein granite was regarded as the earliest deposited of the 'primitive' precipitate rocks. Accordingly, Jameson was forced either to introduce a second phase of granite injection (often describing the vein lithology as syenite, to differentiate it from 'true' granite) or to argue that the granitic veins were in some fashion contemporaneous with their host rocks. Bailey \& Tait (1921, p. 81) commented that "as time went on, Jameson developed the idea of contemporaneous veining well beyond the limits of comprehension." However, there seems little dispute of basic relationships in McCormick's notes from lecture 33 (14 January 1831) which state clearly that "the vein which cuts across the other is always the newest formation", with the point reinforced by an example of four-cross-cutting veins from the Cornish mining field (Figure 3a). Jameson's description of veins depositing 'mineral matter' at the surface is also important as this would seem to accept that the veins (or perhaps more properly dykes) were fed from below (and note McCormick's appended "at different periods"), rather than being either fissure-infills as required by the Neptunist theory, or forming contemporaneously with their host rock as Jameson proposed elsewhere. In contrast, the earlier, 'Dansey' notes, include a diagram of veins formed in conventional Neptunist terms by sequential precipitation into open fissures (Figure $3 b$ ), with a reference to "Werner's new theory of veins" (published in 1809). 
By about 1830 Jameson would appear to have accepted an intrusive origin for larger bodies of granite that had modified their host rocks. Ben Nevis was used as an idealised example, illustrated by McCormick in his notes from Lecture 39 (24 January 1831) (Figure 4). The core of the mountain is shown to be composed of 'granite veined by syenite' and is described as an 'Intermediate Formation'. It appears to have risen-up through and displaced the gneiss, the 'oldest formation' and McCormick added the note that "Granite is thrown up in a soft or fluid state". The mountain is shown as being capped by 'porphyry' described as the 'newest formation', which Jameson might still have regarded as a precipitated rock of Neptunian character. However, the Huttonian influence is clear when McCormick goes on to record "As the granite is forced upwards cracks are formed in the strata of gneiss which are filled by the granite - and fragments of gneiss also become imbedded in the sides of the rock of granite."

A further illustration of Jameson's changing opinion on the origin of granite (and the uplift of strata) is provided by McCormick's notes on the geology of Arran from the series of lectures on the "geognostical structure of Scotland", for example:

The mica-slate - clay-slate $\&$ chlorite slate are the oldest rocks - originally forming horizontal strata at the bottom of the sea and the Granite which is a newer formation on making its way upwards from below raising the strata of slates and sandstones up.

(McCormick, lecture 84, 28 March 1831)

This is not an unequivocal admission that the granite originated as an igneous intrusion of molten rocks, but twelve months later, the anonymous student was more explicit regarding the igneous origin of some, even most, granite. In this summary of the 1831-1832 lectures it is stated that "Primitive rocks are divided into Neptunian and Plutonian" but with granite listed in both categories, and with the important qualifier "Neptunian - Granite - rare of aqueous origin" (pp. 65v-66r). In other words, most granite was igneous and intrusive. When previously lecturing to McCormick (lecture 39, 24 January 1831) Jameson had admitted that "there are no means of distinguishing Plutonian from Neptunian granite."

It is noteworthy that Jameson did not attempt to contradict Hutton in the lecture courses attended by Walker and McCormick when, in marked contrast to the strong rebuttals recorded in the earlier 'Dansey' notes, he simply acknowledged Hutton's observations. Walker's notes for 29 July 1830, from the second of Jameson's two lectures describing the geology of Scotland, includes the following observation: "In Glen Tilt prim nep [primitive Neptunian] and igneous Rocks - here it was Dr Hutton first thought of his theory." McCormick does not mention Hutton but, in the following year, the anonymous student described the "upraising of Primitive Neptunian by Primitive Plutonic rocks" noting that: 
On a small scale it is beautifully seen in Glentilt [sic] near Blair Atholl - a scene also interesting by its importance in the history of Geology - for here Dr Hutton was first led to his interesting views with respect to the Origin of Granite.

(Anonymous notes, p. 126v)

McCormick's omission of Hutton may have arisen from the structure of the lecture course he attended. Although six lectures (84 to 89, 28 March - 5 April 1831) were devoted to the "Geognostical Structure of Scotland" Jameson devoted most of the first three to the geology of Arran, then a fourth to the Hebrides and much of the fifth to Scotland northwards to Ben Nevis. Thereafter he presumably ran out of time and from the sixth and final lecture (89) the "Northern Division" of Scotland has only a twoline summary in McCormick's notes. However, there are two relevant records. Firstly, for Arran:

The granite sometimes forms veins in the surrounding mica-slate - and as veins generally considered newer than formation in which they occur - the mica slates, it would appear have existed prior to the Granite.

(McCormick, lecture 84, 28 March 1831)

Secondly, there is McCormick's description of Ben Nevis (Figure 4):

Ben Nevis ... is formed of Granite-Syenite \& Porphyry all igneous rocks and the surrounding strata of the country are Gneiss, Mica Slate \& Clay Slate - all of Neptunean origin - Rents being formed in these and filled up by the granite and syenite when forcing its way upwards from below - and afterwards - other rents occurring and becoming filled by the Porphyry the newest rock.

(McCormick, lecture 88, 4 April 1831)

These statements demonstrate a substantial shift to Hutton's Plutonism and the abandonment of Jameson's notion that veins were somehow coeval with their host rocks. Nevertheless, writing a year after McCormick, although the anonymous student identified a greater range of intrusive rocks including granite, another variety of granite, together with gneiss and other metamorphic rocks, was still maintained as a Neptunist aqueous precipitate, one of the Primitive lithologies in Werner's wellordered stratigraphy that was perhaps Neptunism's greatest attraction.

\section{Mountain building}


An important point was reached in McCormick's course with lecture 44 on 31 January 1831: "On the age of mountains and the phenomenon and theory of volcanoes." McCormick's notes are illustrated with the largest and most detailed sketch that he made (Figure 5); similar (though smaller and less detailed) sketches appear in the notes of the other 'post-Dansey' students, all presumably copied from an original displayed by Jameson.

In the ideal Neptunist concept the 'primitive' crystalline rocks - gneiss, granite etc. were thought to have been precipitated from a universal ocean: "no detritus; all deposits chemical and very irregularly accumulated" (Bailey \& Tait 1921, p. 80). The irregular accumulation was on a scale sufficient to produce the crystalline cores of subsequent mountain ranges, which were then left locally elevated above the general level of the receding ocean. Hence, "in Transition times a decrease of ocean; crests of primitive mountains appear; detritus mingles with chemical deposit to consolidate the gathering sediment with steep dip on submerged slopes" (Bailey \& Tait 1921, p. 80). A further decrease in the universal ocean then allowed the deposition of detrital and organic beds with more-or-less horizontal stratification. McCormick's sketch (Figure 5) seems, at first sight to follow this pattern, but in fact illustrates an important variant: the mountain ranges are shown to be of different ages, with the dipping 'transition' beds extending to different levels and being overlain (note the unconformities, an essential component of the rival Huttonian model) by different ages of horizontal strata. This sequence of deposition would be incompatible with its control by a steadily decreasing universal ocean. McCormick reinforces the point with a final note at the base of his sketch:

The Himalayan Range is supposed to be of much later origin than the two preceding mountain chains [Pyrenees and 'Alps of Scandinavia'] from the old Alluvial Formation being also a portion of the upraised strata resting on the Mountain Range.

The case for the dynamic uplift of mountain ranges is made more plainly by the anonymous notes from 1831-1832, taken twelve months after McCormick's. Their author wrote: "The Neptunian strata often change their position, by subsidence. More commonly the change is produced by the uprising of Plutonic rocks" (Anonymous notes, p. 74r).

Jameson's lectures on volcanoes were an uneasy mixture of observation and surmise, but he had clearly accepted the basic Plutonist principle:

The --?-- and fluid matter in the centre of the Earth - becoming agitated, attempt to force their way through the crust of the Earth to the surface [and so] produce the phenomenon attending earthquakes and volcanoes. 
A much more informed account was provided for the features of lava flows, which had clearly been studied in some detail. One insight noted by McCormick (lecture 45, 1 Feb 1831) was that, for lava flows recently erupted, "their direction may sometimes be ascertained by an examination of a section of the lava and observing the form of the vesicular cavities."

\section{Religious concerns}

The 'Dansey' notes from about 1820 record Jameson's intention to "point out the agreement of the Mosaic account ... with modern mineralogical discoveries", although they do not describe how that was achieved (see Appendix 1). The only comparable biblical references made by McCormick arose from lecture 50, on 8 February 1831 when Jameson described fossil bones resembling those of elephants, rhinoceros, hyenas and lions that had been found in English caves, and were "supposed to be antidiluvian [sic], or remains of animals drowned at the period of the Deluge." Nevertheless, it was "the opinion of Geologists that the Deluge was not universal, founded on geological phenomena." A further lessening of biblical influence is then apparent from the section of the course dealing with mountain building, a revision forced by Jameson's acceptance that different ranges formed at different times. As recorded by the anonymous student from the 1831-1832 session:

The rising up of a [mountain] chain from the midst of the water would certainly cause a complete or partial deluge. Thus it is probable that the Mosaic deluge may have been the latest of several occasioned by the rising of some elevated chain.

(Anonymous notes, p. 75r)

This retreat from Biblical literalism contrasts with the record of the 'Dansey' notes and strengthens the deduction that they arose from Jameson's lectures some years before the 1830 to 1832 sessions. Jameson would seem to have thought of mountain building as a relatively rapid process of catastrophic uplift. In this he was probably influenced by the ideas of the eminent French naturalist George Cuvier (1769-1832); Jameson had written geological supplements to editions of the English translations of Cuvier's Essay on the Theory of the Earth from 1813 onwards (and in the opinion of Rudwick (2005, p. 510) presented a partisan misrepresentation of Cuvier's research). Catastrophism was a widely held geological belief at the time but was opposed by supporters of Hutton's uniformitarian concept such as Charles Lyell (1795-1875), whose hugely influential book Principles of Geology was, by 1832, inspiring the young Darwin aboard HMS Beagle. 


\section{The importance of Salisbury Crags}

The Edinburgh skyline is dominated by Salisbury Crags (Figure 6), a teschenitic dolerite sill of Late Carboniferous age (e.g. Clarkson \& Upton 2006, p. 171-179) that was used repeatedly by Jameson to illustrate aspects of his geological interpretations. There are many references to it in all the students' notes and several bear particularly on the Neptunist-Plutonist debate.

Hutton had deduced an intrusive origin for the sill largely from features at its base, but in the 'Dansey' notes from c. 1820, more than 20 years after Hutton's death, these features were still described by Jameson in Neptunist terms as demonstrating a transition from an underlying sandstone up into an aqueous precipitate: "Here we may observe the close admixture of the sandstone and greenstone at their point of contact" ('Dansey' volume 2, p. 43r). Jameson used this relationship to make one of his principal anti-Hutton arguments.

In the well known hill of Salisbury Craig there is a succession of strata of greenstone and sandstone alternating with each other, and this being the case, how could the fused trap make its way through the sandstone mass, and divide it into regular strata, parallel to one another, $\&$ to the interposed beds of greenstone. Sandstone is confessedly of aqueous origin $\&$ has never been melted according to the Huttonians in their central furnace, \& yet it is here found alternating with a stone avowedly in their hypothesis of igneous origin, $\&$ preserving a strict parallelism of position throughout its alternations.

('Dansey' volume 2, p. 100r)

Jameson would seem to have maintained a Neptunist position until 1827 if the reminiscences that Darwin recalled in his autobiography can be believed, for example:

I ... heard the Professor, in a field lecture at Salisbury Craigs, discoursing on a trap-dyke, with amygdaloidal margins and the strata indurated on each side, with volcanic rocks all around us, say that it was a fissure filled with sediment from above, adding with a sneer that there were men who maintained that it had been injected from beneath in in a molten condition.

(Barlow 1958, p. 53).

Flinn (1980, p. 254) has questioned Darwin's impartiality and memory, but by 1830 things had certainly changed and Walker recorded in lecture 28, 16 June 1830, that "The greenstone [of] Salisbury Crags is igneous and has come up by the place where the dyke now appears"; he then refers back to a sketch from the previous lecture (Figure 7). The dyke/fissure in question (the later anonymous summary claims two 'feeder' dykes: p. 117v, see below) was perhaps the well-known example at Cat Nick, 
which in fact cuts both the sandstone and the sill; it is a quartz-dolerite with a different composition to the sill itself (Clarkson \& Upton 2006, p. 184).

For McCormick, early in 1831, Jameson introduced Salisbury Crags as an example of inclined strata when defining dip and strike. But McCormick's notes go further and his sketch (Figure 8 ) is accompanied by the following explanation:

The sandstone employed in Building in Edinburgh is of Neptunean or aqueous origin - the sandstone formation of the Salisbury Crags is of the same origin The Greenstone beds of Salisbury Crags is of Plutonian or igneous origin - as also that of Arthur's Seat.

(McCormick, lecture 31, 12 January 1831)

McCormick also made a field visit to Salisbury Craig with Jameson but is uninformative as to the explanation given for its origin. His lecture notebook contains no account and in the second volume of his autobiography (McCormick 1884b, p. 216) he records only that on Saturday 2 April 1831 "at two p.m. accompanied [Jameson] and his class on an excursion to the Salisbury Crags - the geological structure and mode of formation of which, with the hills adjacent, he explained on the spot." A second geological excursion on the following Saturday took McCormick to the summit of Arthur's Seat, Edinburgh's Carboniferous volcano, and whilst for this event some notes were added to his lecture record, they are very general in referring to a succession of basalt, greenstone and sandstone.

The author of the anonymous summary from 1831-1832 was more informative, giving detailed descriptions of the localities visited on Jameson's field excursions. Salisbury Crags and adjacent dykes are unequivocally described as igneous. The following extracts are typical and describe some features that can still be readily observed:

- Salisbury Crag has evidently arisen from below being of igneous origin.

- Plutonic rocks alter the Neptunian rocks as in Salisbury Craigs.

- We find two intimations in the Craig of whence came the Greenstone [the Salisbury Crags sill] - for we find the Sandstone strata broken across ... by two dykes or veins of Greenstone. These were probably originally cracks up which the volcanic matter rose and forced its way between the strata now above and the strata now below, forming a great bed. As it is - this arrangement has been observed in modern volcanoes the - lava being forced up cracks and then in a lateral direction among the strata.

- At a corner standing out - the strata of sandstone and slate are curiously contorted being the effect of the passing upwards of the igneous rocks Farther on in the Greenstone a yellow-coloured slaty mass of slate clay is seen 
- being a fragment brought from below by the boiling matter and changed into a hard mass.

(Anonymous notes, pp. 10, 74, $117 \& 118$ )

The anonymous student also provides an instructive sketch showing the relationship of several of Edinburgh's 'Greenstone' sills (Figure 9). The accompanying text reads as follows:

The sketch shows the progressive breakings up of the Greenstone which is -?through the Sandstone Strata and how it insinuated itself between the Strata till at last it rose into the Crag.

When we find that the Greenstone has altered the Sandstone - breaking and hardening it - we infer that the Greenstone has broken through and been poured upon the already deposited sandstone. But if the superincumbent sandstone be not thus altered we then infer that the Sandstone has been deposited after the uprising of the Greenstone.

The Secondary district of Scotland would seem to have been raised from the bottom of the sea by the agency of these Traps and Porphyries.

(Anonymous notes, p. 126r)

Despite some ambiguity as to whether Salisbury Crags originated as a sill or a lava flow, there is no doubt that Jameson was describing it as an igneous rock, introduced in a molten state via a feeder dyke or dykes. If Darwin's memories were correct, Jameson must have fundamentally changed his opinion between 1827 and 1830 .

\section{Outcomes}

It is clear from the lecture notes of his students that by the early 1830s, Jameson had largely adopted the Plutonist ideas of Hutton, accepting a broad range of igneous rocks as having an intrusive origin, including most granites. His adherence to Neptunism was reduced to that theory's overall stratigraphy, which had a practical utility independent of a causal theory (setting aside the difficulties posed by gneiss and a minority of granites when viewed as aqueous precipitates). For his public conversion Jameson deserves more credit than he has generally been allowed and in this respect the assessment by Flinn (1980) is fairer than the earlier ridicule by Geikie (1897). Sweet (1976) was most probably correct in supposing that Jameson simply bowed to the accumulation of evidence supportive of Hutton's perspective.

Jameson's conversion notwithstanding, for one of his students the residual influence of Neptunism may have been of lasting influence and of profound significance to his future career. McCormick, on completion of his course in Edinburgh, noted in his diary and recalled in his autobiography the following ambition: 
Having now fairly taken up the pursuit of natural history, in addition to my ordinary professional duties, and prepared and qualified myself by a course of hard study and attendance on the lectures of the most distinguished professors, my great object was to get employed in scientific voyages of discovery.

(McCormick 1884b, pp. 217-218).

He must have thought he had achieved this aim when appointed in 1831 to HMS Beagle which was to carry Darwin around the world over the next five years and, in doing so, initiated a scientific revolution. McCormick might have expected to find in Darwin, another of Jameson's students, a fellow adherent to Neptunist geology. However, before attending Jameson's lectures in 1827, Darwin had enjoyed the more flamboyant course offered by Thomas Hope, Professor of Chemistry and so was "predisposed to find Jameson dull" (Browne 1995, p. 70). Hope promoted Hutton's Plutonism and Darwin thereafter thought little of Jameson's Neptunist geology. McCormick, having been primed and befriended by Jameson, attended only one of Hope's lectures, the introductory lecture to the summer 1831 course, just before he returned to London (McCormick 1884b, p. 217). This fundamental difference in their geological educations must have been one of the issues that led Darwin to dismiss McCormick as "a philosopher of rather an antient date" (from a letter to John Henslow quoted by Browne 1995, p. 202), and would have aggravated the circumstances that led McCormick to abandon the Beagle voyage early in 1832 (see Appendix 1).

Ultimately, McCormick achieved his ambition whilst serving as senior surgeon on the 1839-1843 Antarctic expedition led by James Clark Ross (1800-1862) (see Appendix 1). In the first volume of his autobiography which described his experiences during that voyage, McCormick (1884a) included within chapter seventeen a summary of what he saw as the essentials of geology. It shows that, in the 1880s, he was still influenced by the Wernerian global stratigraphy taught to him by Jameson fifty years earlier; the following extract could have been taken directly from his 1830-1831 lecture notes:

The lowermost rock in the crust is granite, this passing into gneiss, and above these lies [rock] made up of the disintegrated granite and gneiss, syenite being a subsequent eruption to the granite, and differing from it ... Above these Plutonic rocks we have the argillaceous schists and sandstones, and the various other sedimentary strata of the limestone and sandstone formations, through which the igneous rocks have been erupted through volcanic action, or upheaved the strata from the original horizontal position at various periods. 
There is some irony in McCormick's notes bearing witness to Jameson's conversion to Plutonism given this long-term adherence to at least some of the early ideas of his mentor.

Whilst McCormick had a high opinion of his own scientific abilities, other commentators have considered him a routine collector with little interest in the wider relationships of his subjects and insufficient talent to investigate them further (e.g. Jones 1982). There is, however, one exception to that seeming lack of imagination when, at several points in his autobiography, McCormick speculates over the causes of climate change and implications of fossils such as corals now found in the Polar regions. Writing of fossils that he collected in the Arctic in 1853 he was impressed that:

Creatures constructed as these are could only exist in the warmest regions, therefore must have at some period or other lived in a tropical, or at least a sub-tropical climate here. For the very perfect condition of the delicate organization these are found in, precludes all supposition as to their having been transported from any distance.

(McCormick 1884b, p. 85).

Perhaps this line of reasoning can also be traced back to Jameson's influence. Walker noted on 5 May 1830, from the second lecture of his summer course, Jameson's conclusion that the British climate was now cooler than it had been in the past, citing fossil rhinoceros, hippopotamus and elephants as "remnants of a bygone age and of a warmer climate." When the same idea was presented at a later stage in McCormick's course he seems to have been amused by Jameson's visual aid:

When these animals existed England is supposed by Geologists to have possessed a tropical climate - illustrated by a drawing of the South of England clothed in tropical scenery with these animals sporting about.

(McCormick, lecture 51, 9 February 1831).

This demonstration followed Jameson's description in McCormick's previous lecture (lecture 50, 8 February 1831) of the discovery of "fossil bones resembling hyenas, lions and tigers" in caves in England, that were "supposed to be antidiluvium [sic] or remains of animals drowned at the period of the Deluge." Jameson's artistic inspirations most probably included the 1822 discoveries made by William Buckland (1784-1856) in Kirkland Cave, Yorkshire, although Buckland's faunal list did not include lions and he correctly inferred that the bones of other large mammals amongst them elephant, rhinoceros, hippopotamus, bison and giant deer - had been carried into the cave by the resident hyenas (Buckland 1823). Buckland's research at 
Kirkdale had created an international sensation (Rudwick 2005, pp. 625-638) and would have been familiar to Jameson.

\section{Epilogue}

As an extraordinary addendum to his lecture notes, McCormick provides a complete list of all the items exhibited in Jameson's museum, recording in his autobiography (McCormick 1884b, p. 216) that on 20 April 1831 he "visited the museum and completed the list I had been making during the winter, of the specimens of natural history contained in it." There are no comments on the various exhibits, it is simply a list that runs to 52 sides of his notebook pages $(195 \mathrm{~mm} \times 135 \mathrm{~mm}$ ) with writing that becomes very small and dense as he ran out of space. It confirms the extraordinary range of material that Jameson had accumulated, and amongst the 1500 bird specimens listed was one that McCormick claimed to recognise as having shot himself and skinned on 15 June 1827, near Svalbard, during his first Arctic incursion (McCormick 1884a, p. 396).

It is surprising that none of the specimens collected by McCormick during his subsequent travels found their way into Jameson's hands, given his subsequent fond recollection of "my late lamented friend, Professor Jameson" (McCormick 1884a, p. 396). Instead, McCormick's surviving geological specimens are now held by The Natural History Museum, London (Stone 2020 a, b). Some were included in the 'official' contribution to the British Museum that was deposited by James Clark Ross in 1844, soon after the return of the 1839-1843 Antarctic expedition. Other specimens from that expedition were retained by McCormick and together with additional, mostly Arctic material, were bequeathed to the British Museum on his death in 1890.

\section{Acknowledgements}

Grateful thanks are due to the staff of the following institutions for their assistance in locating archival material: Wellcome Collection, London; National Library of Scotland, Edinburgh; Edinburgh University Centre for Research Collections; National Museum of Scotland, Edinburgh; The Natural History Museum, London; British Geological Survey, Edinburgh. The perceptive comments of an anonymous referee led to significant improvements in the paper.

\section{Funding}

This research received no financial assistance from any funding agency.

\section{Appendix 1.}

\section{The students and their notebooks}




\section{William Scoresby}

Notebooks relating to Scoresby junior's studies at Edinburgh University, Scoresby Archive, Whitby Museum.

William Scoresby enrolled at Edinburgh University in the winters of 1806-1807 and 1808-1809; his summers were spent whaling in the Arctic. During the second winter he attended Jameson's lecture course and the two men became friends and long-term scientific correspondents. In 1808 Scoresby would have heard Jameson deliver a faithful account of Werner's Neptunist geological theory, but geology did not feature significantly in Scoresby's subsequent Arctic investigations, carried out in parallel with his whaling operations. He was concerned principally with terrestrial magnetism (for its importance to navigation), oceanography, the physics of ice, and aspects of whaling and whale biology (Scoresby 1820). In later life Scoresby turned to religion and was ordained an Anglican minister in 1825, having been elected a Fellow of the Royal Society in the previous year. A comprehensive biography has been provided by Stamp \& Stamp (1975). His Edinburgh University notebooks form part of an extensive archive of Scoresby material held by the Whitby Museum. Whitby was Scoresby's hometown and the base for his whaling voyages.

\section{William Dansey}

Notes on lectures in natural history, c. 1820. Centre for Research Collections, University of Edinburgh.

Two undated notebooks contain an incomplete summary of Jameson's lecture course, copied-up subsequent to the student's attendance at the lectures. Each notebook carries a book plate from the library of the Rev. William Dansey (1792-1856), Rector of Donhead St Andrew, Wiltshire, but there is no evidence that Dansey attended Jameson's lectures. Instead, he graduated in classics (BA 1814, MA 1817) and medicine (BM 1818) at Exeter College, Oxford, and was then ordained in 1819 (Boase \& Curthoys 2004). How he came by the notebooks, and the identity of the original student, are both unknown

The summary covers only meteorology, hydrography, mineralogy (which included geology) and the concluding zoological lectures concerned with Man; blank pages suggest intended additions that were never made; individual lectures are not identified. The emphatic presentation of orthodox Neptunism and biblical literalism, the latter emphasised by Jameson's stated intention to cover "the different theories of creation, \& point out the agreement of the Mosaic account, in all its stages, with modern mineralogical discoveries", both suggest an early date relative to the surviving notes from the early 1830s which treat these issues very differently. Sadly, the student does not record details of the reconciliation with the Mosaic account. 
The notebooks are mostly written folio-style, with diagrams and some additional notes inserted on verso pages; the additions are in the same hand as the main text. Jenkins (2016) drew attention to references in the verso notes to papers published in the Edinburgh Philosophical Journal for 1826. From that, he deduced the original notetaking to have occurred in 1826 or soon thereafter. However, because the additional notes may have been added later, to a text that was itself copied from original notes taken earlier, that date may not be valid. Because it sets the latest date for Jameson's delivery of conventional Neptunism, the timing of the 'Dansey' notetaking is of some importance.

An indication of that date might be provided by the reading list recorded on the first two pages of the first 'Dansey' notebook. It lists titles definitively published between 1776 and 1816. Some references are ambiguous: for example, "Cuvier's Theory of the Earth" might refer to the book published (in French) in 1821, or perhaps more probably to Cuvier's Essay on the Theory of the Earth for the English translations of which, published in 1813 and 1815, Jameson had written geological supplements. Perhaps more significant is an omission from the reading list. Jameson recommended several of his own works including his System of Mineralogy, stressing 'latest edition', presumably the second (1816) or third (1820) editions. Not listed is Jameson's Manual of Mineralogy published in 1821. It would seem almost certain that Jameson would have recommended his most recent textbook, and the Manual was certainly used by subsequent students; Darwin's annotated copy from 1827 is held by Cambridge University Library.

For the purposes of this paper a c. 1820 date is taken for the 'Dansey' lecture course rather than the 1826 date proposed by Jenkins (2016). The earlier date is also supported by two further, admittedly circumstantial clues. Firstly, the summary lecture text is interspersed with first-hand descriptions of independent geological excursions, some around Edinburgh but others in southern England. One of the latter is dated 29 August 1818 and whilst it is not clear how this event relates to the timing of the Edinburgh notes, it does show that the author was geologically active at that date. Secondly, a reference to ocean temperatures in one of the hydrography lectures, cites the Antarctic, 'farthest south' position achieved by James Cook in 1774. Cook's record was bettered in 1823 by James Weddell, albeit Weddell did not return with the news until 1824. His home port was Leith, now the harbour district of Edinburgh, and on his return Weddell donated specimens to Jameson's museum (Weddell 1827, pp. 22-23, 324), including the type specimen of what became the Weddell Seal, Leptonychotes weddellii (Lesson 1826). Jameson would quickly have heard of the new 'farthest south' record.

\section{W. S. Walker}

Notes on lectures in natural history, 1830. National Library of Scotland, Edinburgh, 
This is one of thirteen notebooks recording Walker's notes from lectures in the humanities, ancient history, Greek, logic, moral philosophy, natural history, mathematics, divinity and law: Mss 14142-14154. Walker attended the summer lecture course immediately preceding the winter course attended by McCormick. Nothing is known of Walker's future career, but the combination of subjects studied suggests that he was destined either for law or the Church. His text is untidy, with a hastily written appearance and is difficult to follow in places; possibly these are original notes rather than a subsequent copy.

\section{Robert McCormick}

Notes from Lectures on Natural History delivered in the Edinburgh University by Professor Jameson during the Winter of 1830-31. Wellcome Collection, London.

A Royal Navy surgeon, Robert McCormick (1800-1890) is the only one of the students whose notes have survived who is known to have maintained geological interests into later life. Between 19 November 1830 and 15 April 1831, he attended Jameson's course of 97 lectures and his notes are the most complete of the available records, with each lecture numbered and dated (but individual notebook pages are not numbered). With appropriate Naval discipline he attended and described every lecture, but of course his notes may still not be a full account.

For his biography of McCormick, Jones (1982) utilised some of the Wellcome Collection papers but made only passing reference to the character of Jameson's geology as revealed therein. Browne (1995, p. 70) thought that McCormick's account "suggests that the lectures were both comprehensive and useful, although failing to cover anything like so complete a syllabus as promised." This criticism is probably less appropriate for the geology lectures than for other parts of the course.

McCormick had qualified as a surgeon and joined the Royal Navy in 1823, serving in the West Indies and British coastal waters before joining an 1827 expedition seeking to reach the North Pole. That expedition failed in its main objective - McCormick got no further north than Svalbard - but the experience initiated his long-term interest in the Polar regions. He subsequently made extended voyages to both the Antarctic and the Arctic; to the former with the 1839-1843 expedition led by James Clark Ross, and to the latter in 1852-1853 with one of the missions sent out to search, unsuccessfully, for the lost expedition led by John Franklin (1786-1847) (Stone 2020a; 2020b). These involvements in 19th century Polar voyages were celebrated by McCormick in his two-volume autobiography (McCormick 1884a, 1884b). This rather loquacious work of self-promotion has stimulated two subsequent biographies: Keevil (1943) was charitable, Jones (1982) was more critical.

Notable for its absence from his autobiography is any mention of another voyage, that of HMS Beagle. McCormick could have circumnavigated the globe with Darwin, and on learning of his appointment, Jameson wrote enthusiastically urging McCormick to 
make the most of the collecting opportunities that would arise (Browne 1995, p. 205). In the event, McCormick's inability to reconcile his own role with the activities of Darwin is well documented and much discussed (e.g. Desmond \& Moore 1991; Browne 1995; Steel 2011) and led to him leaving the ship early in the voyage. He would appear to have maintained a long-term antipathy to Darwin who is never mentioned in the autobiography, with HMS Beagle only referred to anonymously as "a ten-gun brig".

\section{An anonymous student}

Notes of natural history lectures by Professor Jameson. 1831-1832. National Library of Scotland, Ms. 3936.

This anonymous record is a neat, fair-copied summary of the lecture course. Individual lectures are not separated, and the themes covered are merged into an essay-style report, illustrated with carefully drawn sketches, some coloured. Noteworthy inclusions are detailed accounts of Jameson's field excursions to Salisbury Crags and Arthur's Seat. The notebook was originally held by the Royal Scottish Museum (now National Museum of Scotland) and was passed to the National Library in 1952. Curiously, it also contains notes on ornithology and entomology in different handwriting to that of the geology notes; perhaps student note-taking was a team effort.

\section{B. Ramsay}

Lecture notes on 'Natural History III', 1835-1836. Special Collections, University of Glasgow.

The notes show that the principal components of Jameson's 1835 geology lectures were maintained as recorded by the three previous students from the early 1830s. Ramsay's notes were described by Jenkins (2016, p. 533, footnote 4) as a "very full account of the Neptunian theory", although, as will be shown in this paper, by 1835 Jameson had moved away from many aspects of orthodox Neptunism. Three notebooks cover the full range of Jameson's course, a fourth contains incomplete notes on astronomy: Cullen 281-284. Ramsay gives his address as 80 George Street, Edinburgh. Nothing is known of his future career.

The notebooks were donated to the University of Glasgow in 1920 by Professor J. M. Thomson of King's College, London, in association with a collection of documents relating to William Cullen (1710-1790) and John Thomson (1765-1846), both of whom had been medical academics in Glasgow.

\section{References}


Bailey, E.B. \& Tait, D. 1921. Geology. In: Knott, C. G. et al. (eds) Edinburgh's Place in Scientific Progress. Published for the Edinburgh Meeting of the British Association, W. \& R. Chambers, Edinburgh \& London.

Barlow, N. (ed.). 1958. The Autobiography of Charles Darwin, 1809-1882. With the original omissions restored. Collins, London.

Boase, G.C. \& Curthoys, M.C. 2004. Dansey, William (1792-1856). In: Matthew, H.C.G. \& Harrison, Brian (eds) Oxford Dictionary of National Biography, 15, 93-94.

Browne, J. 1995. Charles Darwin: Voyaging. Jonathon Cape, London.

Buckland, W. 1823. Reliquiae diluvianae. John Murray, London.

Chitnis, A.C. 1970. The University of Edinburgh's Natural History Museum and the Huttonian-Wernerian Debate. Annals of Science, 26, 85-94.

Clarkson, E \& Upton, B. 2006. Edinburgh Rock: the geology of Lothian. Dunedin Academic Press, Edinburgh.

Davies, G.L. 1969. The Earth in decay. A history of British Geomorphology 15781878. MacDonald, London.

Desmond, A. \& Moore, J. 1991. Darwin. Michael Joseph, London.

Devlin, C.L. 2019. William Scoresby as an Arctic physical oceanographer, Archives of Natural History, 46, 33-43.

Fitton, W.H. 1839. Book review: Elements of Geology by Charles Lyell. The Edinburgh Review, 69, 406-466.

Flinn, D. 1980. James Hutton and Robert Jameson. Scottish Journal of Geology, 16, 251-258.

Geikie, A. 1897. The founders of geology. Macmillan, London.

Jameson, L. 1854. Biographical Memoir of the late Professor Jameson. The Edinburgh New Philosophical Journal, 57, 1-49.

Jameson, R. 1826. Notes on the geology of the countries discovered during Captain Parry's second and third expeditions. In: Parry, W.E. Journal of a third voyage for the discovery of a north-west passage from the Atlantic to the Pacific; performed in the years 1824-25, in His Majesty's ships Hecla and Fury. Appendix, 132-151. John Murray. London

Jenkins, B. 2016. Neptunism and Transformism: Robert Jameson and other Evolutionary Theorists in Early Nineteenth-Century Scotland. Journal of the History of Biology, 49, 527-557. 
Jones, A.G E. 1982. Robert M'Cormick, Deputy Inspector-General Royal Navy. The Great Circle, 4, 84-91.

Keevil, J.J. 1943. Robert McCormick, R. N. The stormy petrel of Naval medicine. Journal of the Royal Naval Medical Service, 29, 36-62.

Laudan, R. 1987. From mineralogy to geology - The foundations of a science, 1650 1830. University of Chicago Press, Chicago \& London.

Lee, G. W. 1912. Note on Arctic Palaeozoic fossils from the "Hecla" and "Fury" collections. Proceedings of the Royal Physical Society of Edinburgh, 18, 255-264.

Lesson, R.P. 1826. Sur le Phoque Léopard de Mer (Sea Leopard) des Orcades australes. Bulletin des sciences naturelles et de géologie, 7, 437-438.

McCormick, R. 1884a. Voyages of discovery in the Arctic and Antarctic seas, and round the world. 1. Samson Low, Marston, Searle \& Rivington, London.

McCormick, R. 1884b. Voyages of discovery in the Arctic and Antarctic seas, and round the world. 2. Samson Low, Marston, Searle \& Rivington, London.

Rudwick, M.J.S. 2005. Busting the limits of time - The reconstruction of geohistory in the Age of Revolution. University of Chicago Press, Chicago \& London.

Scoresby, W. 1820. An account of the Arctic Regions, with a history and description of the northern whale-fishery. Constable, Edinburgh.

Secord, J.A. 1991a. The discovery of a vocation: Darwin's early geology. British Journal for the History of Science, 24, 133-157.

Secord, J.A. 1991b. Edinburgh Lamarckians: Robert Jameson and Robert E. Grant. Journal of the History of Biology, 24, 1-18.

Stamp, T. \& Stamp, C. 1975. William Scoresby, Arctic Scientist. Caedmon, Whitby.

Steel, E. 2011. He Is No Loss: Robert McCormick and the voyage of HMS Beagle. British Society for the History of Science, Monograph 14. London.

Stone, P. 2020a, in press. Robert McCormick's geological collections from Antarctica and the Southern Ocean, 1839-1843. Archives of Natural History.

Stone, P. 2020b, in press. Robert McCormick and the circumstances of his Arctic fossil collection, 1852-1853. Archives of Natural History.

Sweet, J.M. 1976. Introduction. In: White, George W. (ed.) The Wernerian theory of the origin of rocks by Robert Jameson, 1808. Contributions to the History of Geology, 9, xii-xxiv.

Sweet, J.M. \& Waterston, C.D. 1967. Robert Jameson's approach to the Wernerian Theory of the Earth, 1796. Annals of Science, 23, 81-95. 
Weddell, J. 1827. A voyage towards the South Pole performed in the years 1822-24. Longman, Rees, Orme, Brown \& Green, London.

\section{Table 1}

\begin{tabular}{|c|c|c|c|}
\hline Student & Date of attendance & Location of notes & Catalogue number \\
\hline William Scoresby & $1808-1809$ & Whitby Museum & \\
\hline $\begin{array}{l}\text { Anonymous, but } \\
\text { ex libris Rev. } \\
\text { William Dansey }\end{array}$ & $\begin{array}{l}\text { Unknown but } \\
\text { probably ca. } 1820\end{array}$ & $\begin{array}{l}\text { Edinburgh } \\
\text { University, Centre } \\
\text { for Research } \\
\text { Collections }\end{array}$ & Dc.3.33 \& 34 \\
\hline W. S. Walker & 1830 & $\begin{array}{l}\text { National Library } \\
\text { of Scotland, } \\
\text { Edinburgh }\end{array}$ & Ms. 14148 \\
\hline $\begin{array}{l}\text { Robert } \\
\text { McCormick }\end{array}$ & $1830-1831$ & $\begin{array}{l}\text { Wellcome } \\
\text { Collection, } \\
\text { London }\end{array}$ & Ms. 3358 \\
\hline Anonymous & $1831-1832$ & $\begin{array}{l}\text { National Library } \\
\text { of Scotland, } \\
\text { Edinburgh }\end{array}$ & Ms. 3936 \\
\hline D. B. Ramsay & $1835-1836$ & $\begin{array}{l}\text { Glasgow } \\
\text { University, Special } \\
\text { Collections }\end{array}$ & Ms. Cullen 283 \\
\hline
\end{tabular}

A summary of data for the six students' notebooks known to record Robert Jameson's lecture course in natural history

\section{Figures 1-9}




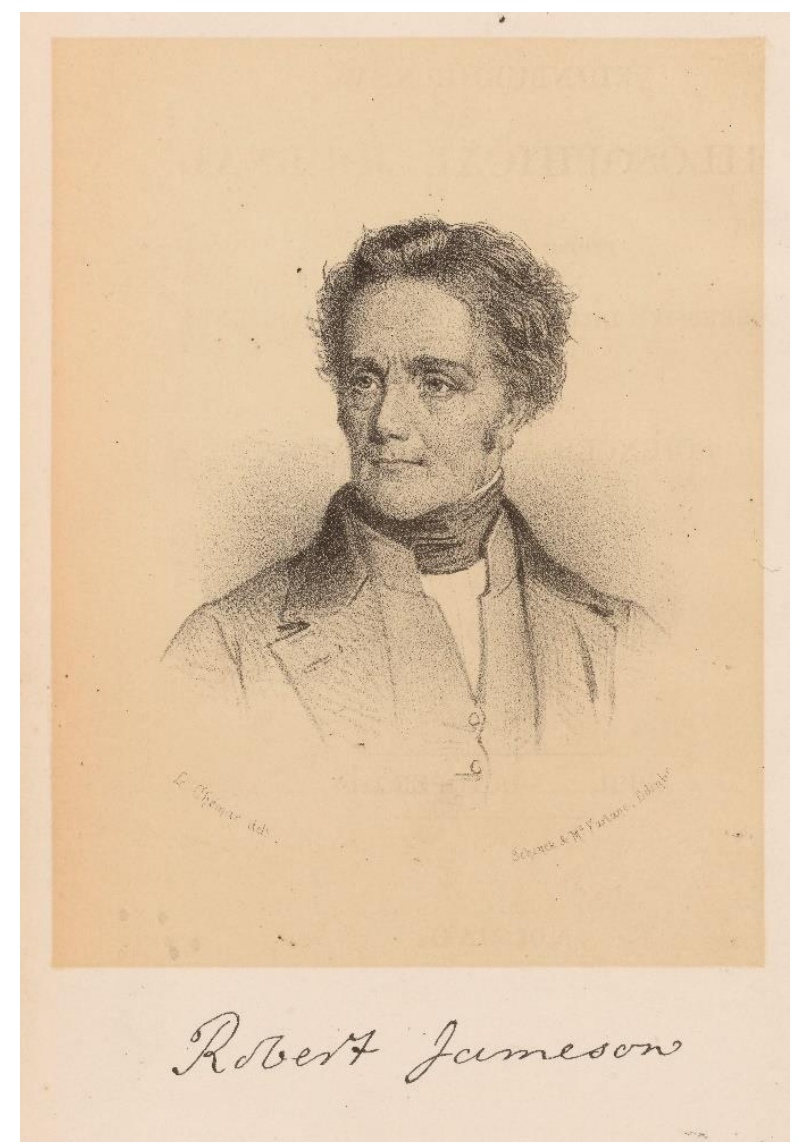

Figure 1. Robert Jameson (1774-1854) in later life. This portrait accompanied the obituary in The Edinburgh New Philosophical Journal that was compiled by Jameson's nephew Laurence Jameson (1854). Image courtesy of the National Library of Scotland.

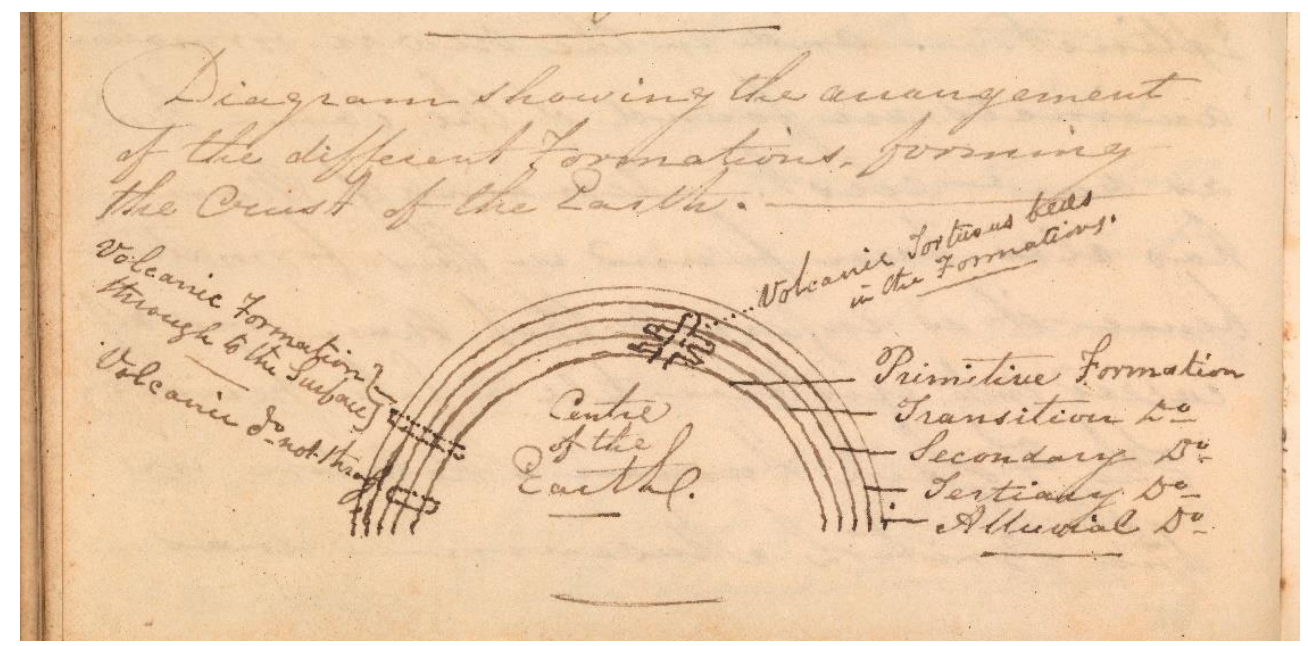

Figure 2. The Neptunist model of the Earth's crust recorded by McCormick from Jameson's lecture 37 on 20 January 1831. The notebook page is $135 \mathrm{~mm}$ wide. Image courtesy of the Wellcome Collection, London. 

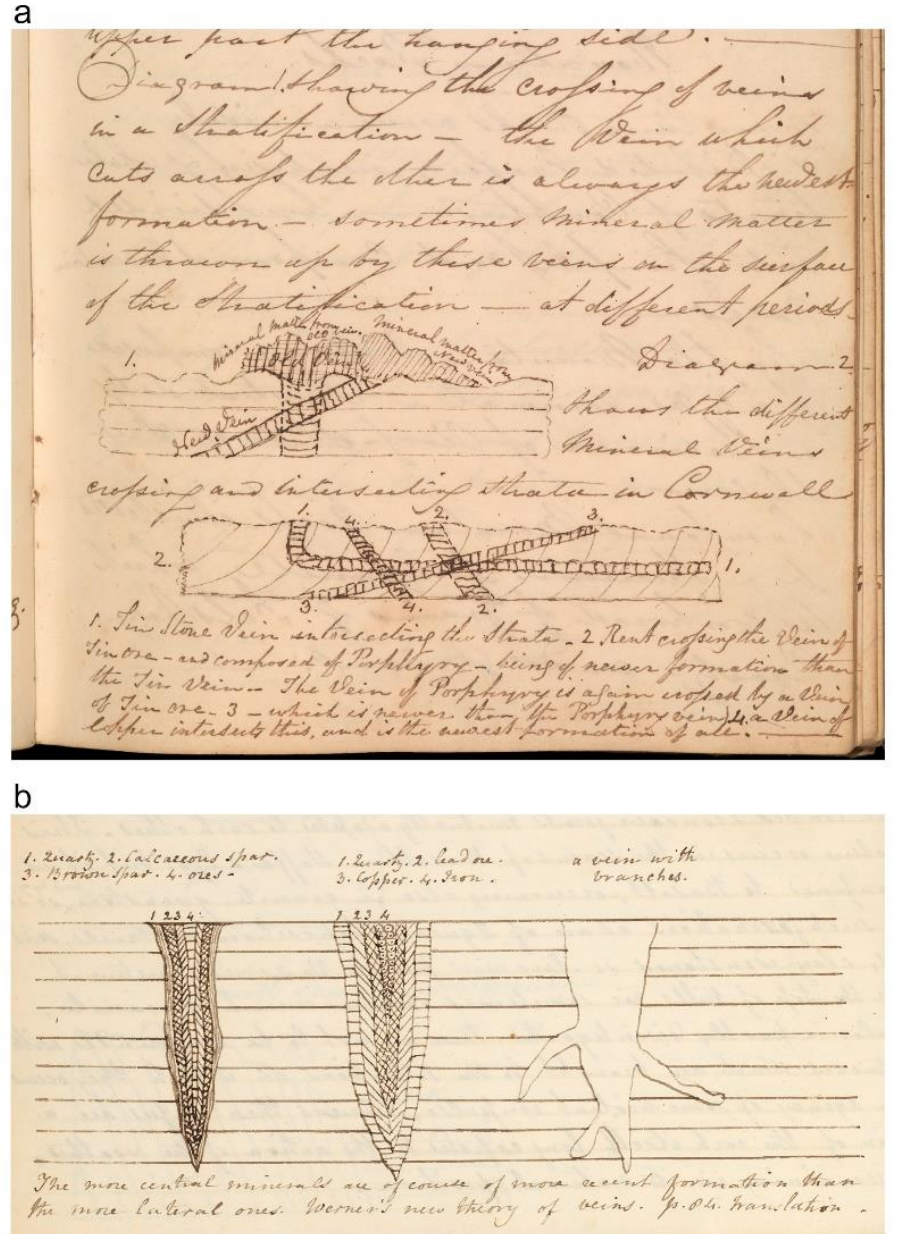

Figure 3.

a. Cross-cutting veins and/or dykes as recorded by McCormick from Jameson's lecture 33 on 14 January 1831, the notebook page is $135 \mathrm{~mm}$ wide. Image courtesy of the Wellcome Collection, London.

b. A sketch from the 'Dansey' notes, c. 1820, illustrating the Neptunist view of veins then promoted by Jameson. Notebook p. 57v, the page is $200 \mathrm{~mm}$ wide. Image courtesy of Edinburgh University Centre for Research Collections.

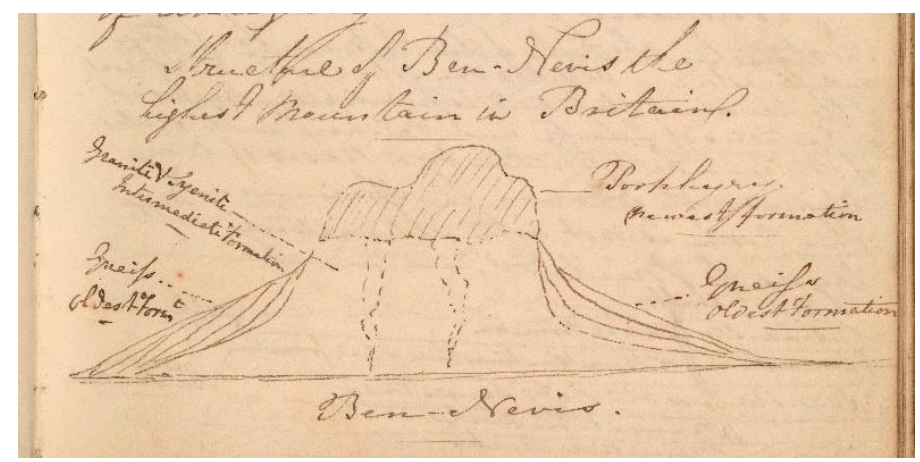

Figure 4. McCormick's sketch showing the geology of Ben Nevis as recorded from Jameson's lecture 39 on 24 January 1831. The notebook page is $135 \mathrm{~mm}$ wide. Image courtesy of the Wellcome Collection, London. 


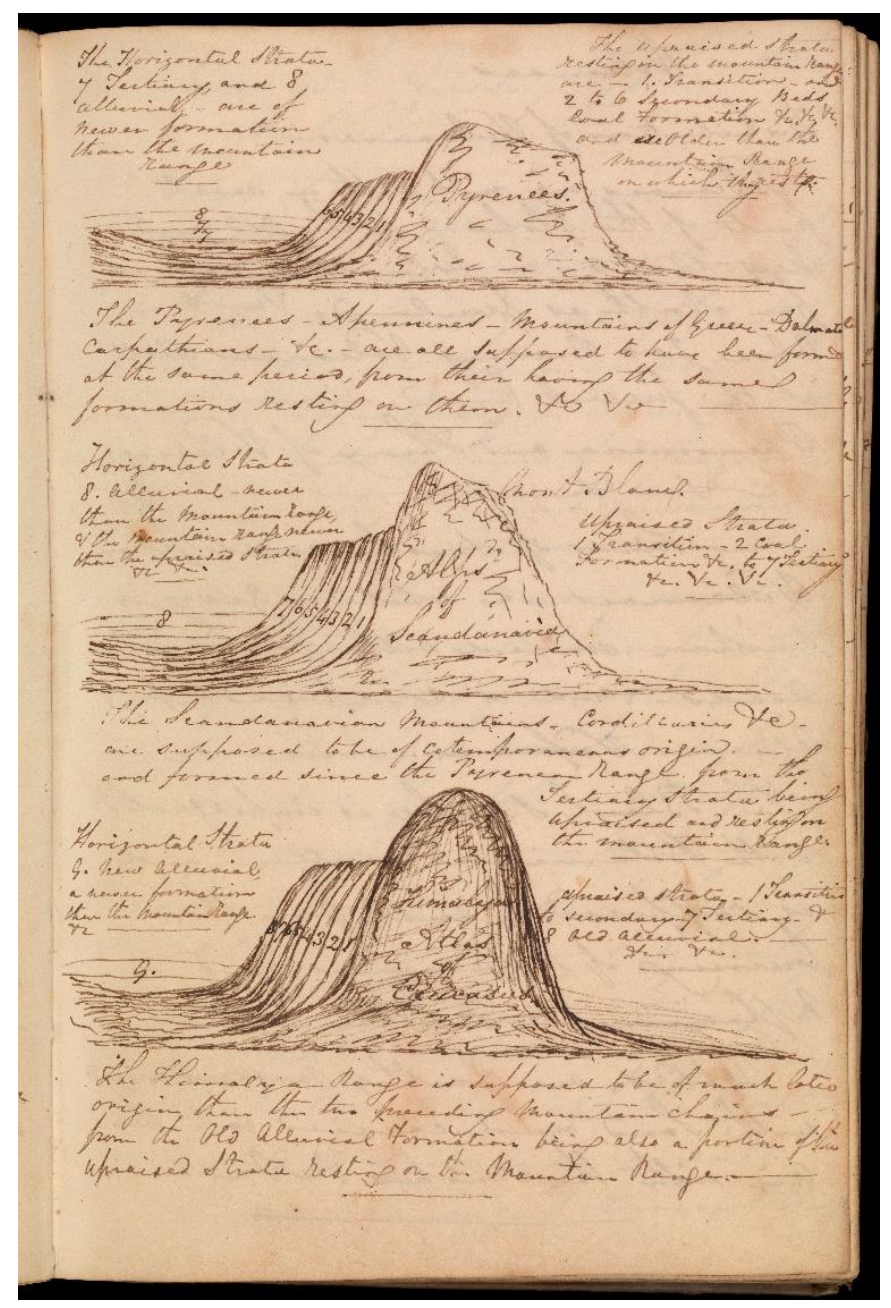

Figure 5. McCormick's sketch illustrating the process and different ages of mountain building as recorded from Jameson's lecture 44 on 31 January 1831. The notebook page measures $195 \mathrm{~mm}$ x $135 \mathrm{~mm}$. Image courtesy of the Wellcome Collection, London.

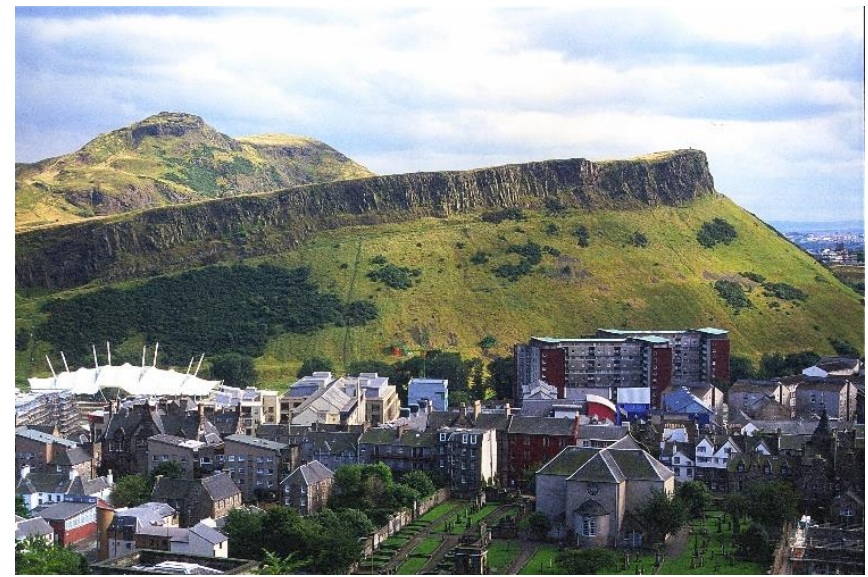

Figure 6. The dramatic skyline of Edinburgh created by Salisbury Crags, with Arthur's Seat looming in the background. BGS image P 517429. 


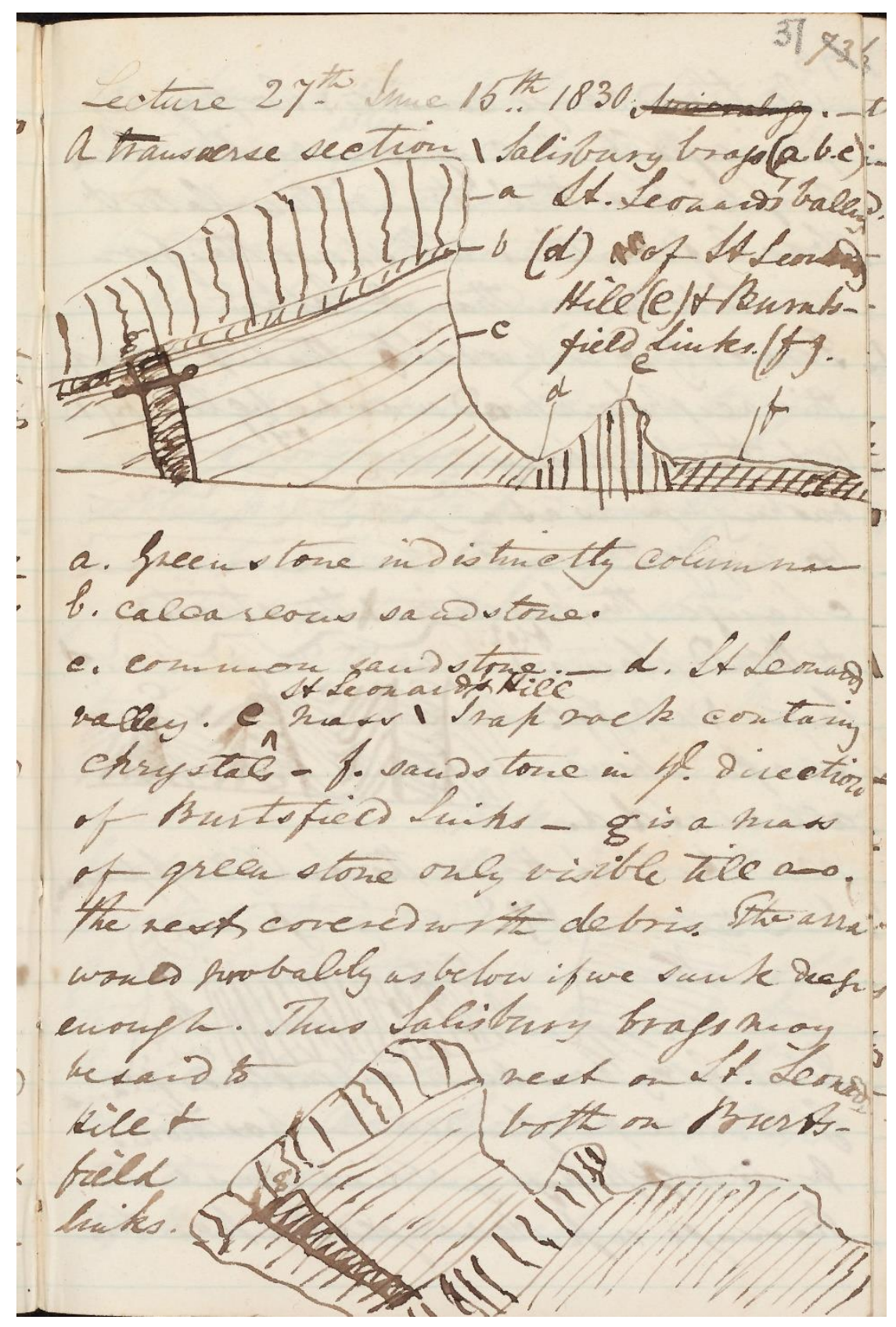

Figure 7. Walker's sketches of Salisbury Crags showing a sill or lava flow fed by a dyke as recorded from Jameson's lecture 27 on 15 June 1830. Notebook p. 37r. The notebook page measures $200 \mathrm{~mm}$ x $130 \mathrm{~mm}$. Image courtesy of the National Library of Scotland. 


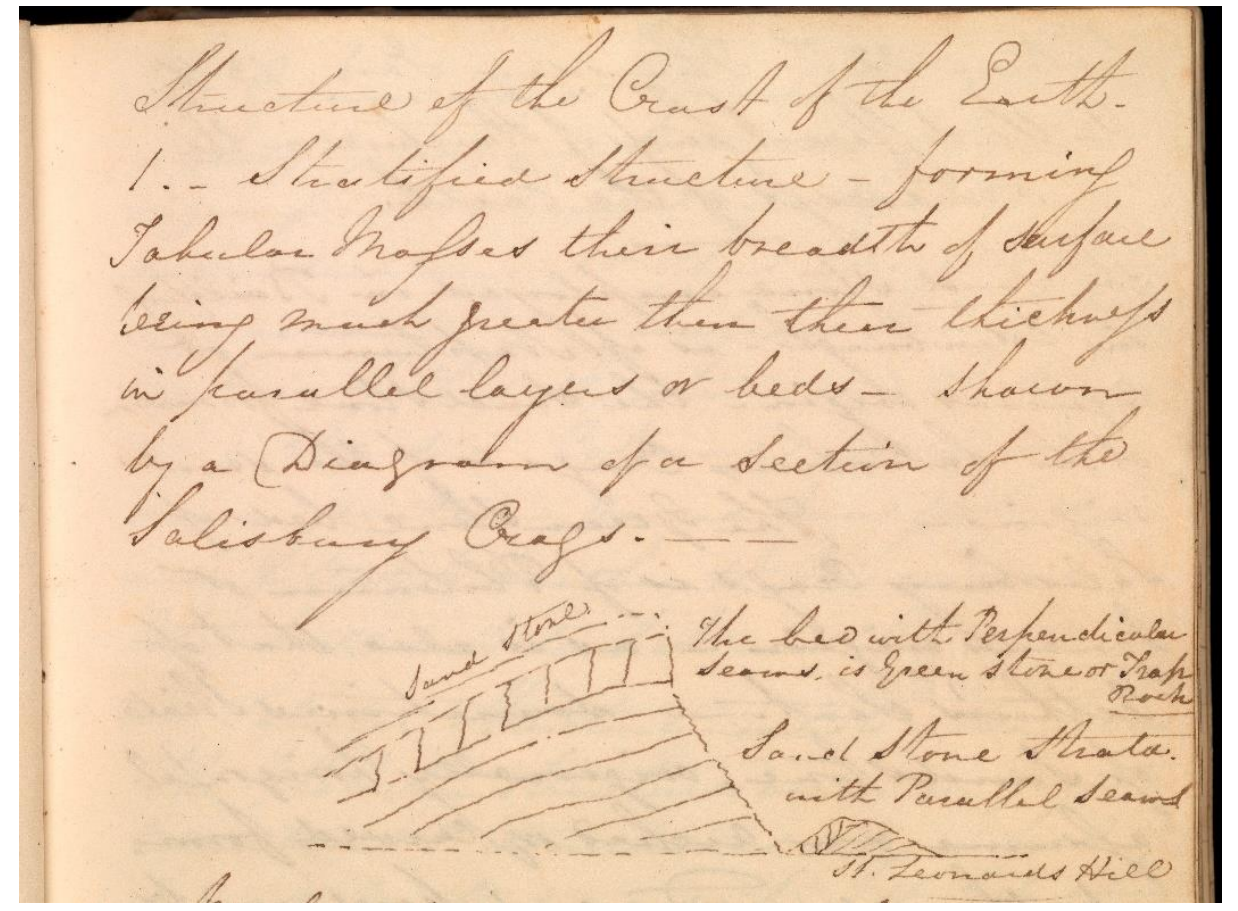

Figure 8. McCormick's sketch showing the geology of Salisbury Crags as recorded from Jameson's lecture 31, Wednesday January 12, 1831. The notebook page is 135 $\mathrm{mm}$ wide. Image courtesy of the Wellcome Collection, London.

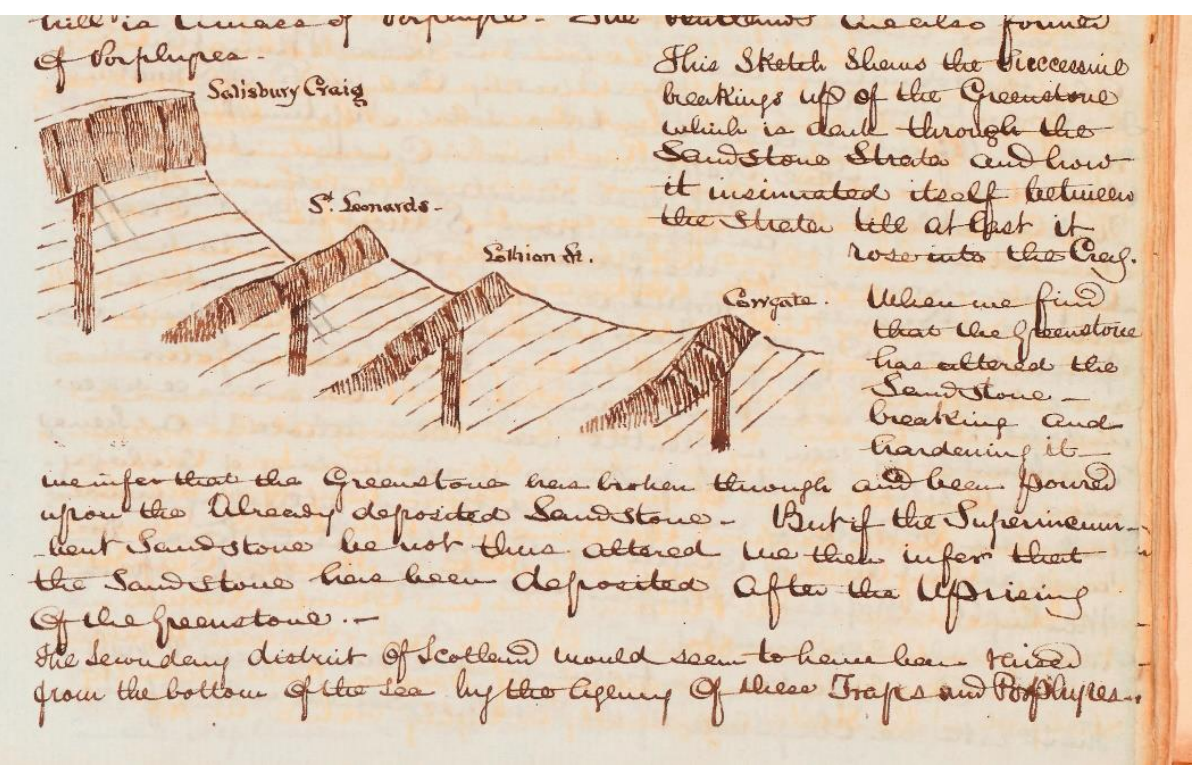

Figure 9. The interpretation of Salisbury Crags as the culmination of a series of sills, as recorded by the anonymous student in his summary of Jameson's lecture course, 1831-1832. Notebook p. 126r, the page is $175 \mathrm{~mm}$ wide. Image courtesy of the National Library of Scotland. 